\title{
Effects of Dietary Glutathione on Plasma and Liver Lipid Levels in Rats Fed on a High Cholesterol Diet
}

\author{
Kimio SugiYama, Kayoko OHISHI and Keiichiro Muramatsu \\ Laboratory of Food and Nutrition, Department of Agricultural Chemistry, \\ Faculty of Agriculture, Shizuoka University, Ohya 836, Shizuoka 422, Japan \\ Received December 5, 1986
}

\begin{abstract}
The effects of dietary glutathione (GSH) on plasma and liver lipid concentrations were investigated with rats fed on a high cholesterol diet. When graded levels of GSH, 0.75 to $5.0 \%$, were added to the $25 \%$ casein basal diet, the plasma total cholesterol level was significantly decreased and the HDL-cholesterol level was inversely increased in all addition levels without influence on the growth of animals except for the 5\% addition level; the dietary addition of 5\% GSH markedly depressed the growth and food consumption of rats and caused a slight diarrhea. Plasma triglyceride and phospholipid levels were decreased by the dietary addition of GSH. The contents of cholesterol and triglyceride in the liver were decreased as the dietary addition level of GSH was increased. The dietary addition of a mixture of glutamic acid, cysteine and glycine, or cysteine alone corresponding to $2.5 \%$ GSH resulted in a cholesterol-lowering effect which could not be distinguished from the effect of GSH in rats fed on the $25 \%$ casein diet. When $1.5 \% \mathrm{GSH}$ was added to a low $(10 \%)$ casein diet, the plasma cholesterol-lowering effect of GSH was also observed and the effect was comparable to that of cysteine. These results indicate that dietary-added GSH has a plasma and liver cholesterol-lowering efficacy and that this effect is largely attributable to the cysteine residue of GSH rather than to the tripeptide itself or the other amino acid residues.
\end{abstract}

The plasma cholesterol level is influenced by various dietary components including proteins and amino acids. ${ }^{1 \sim 7)}$ Of the amino acids constituting dietary proteins, sulfur-containing amino acids such as methionine and cystine have the most intense effect on the plasma cholesterol level in rats fed on a high cholesterol diet. ${ }^{8)}$ It has been reported that dietary addition of methionine results in an enhancement of plasma cholesterol level in rabbits ${ }^{1,9)}$ and rats ${ }^{10 \sim 14)}$ although methionine lowers the plasma cholesterol level when added to lowmethionine diets containing cholesterol. ${ }^{12,15 \sim 17)}$ The dietary addition of metabolites of methionine such as homocystine, ${ }^{14)}$ cysteine, or cystine ${ }^{11,12,14,16,18,19)}$ and taurine, ${ }^{16,18,20 \sim 22)}$ on the contrary, has been shown to decrease plasma or serum cholesterol levels in experimental animals. Several sulfur amino acids such as methionine, homocystine, and cystine cause toxic effects when they were included in the diet at excess levels. ${ }^{23 \sim 25)}$
Taurine has little toxic effect, but it has also little growth-promoting effect in experimental animals unlike other methionine metabolites with toxic effects. ${ }^{25)}$ Glutathione (GSH) is an another sulfur-containing compound which is known to exist in animal tissues at relatively high levels. In an earlier report, Mann ${ }^{18)} \mathrm{dem}$ onstrated the serum cholesterol-lowering effect of GSH in monkeys. However, detailed study on the effect of GSH on lipid metabolism has not been reported.

In this study, therefore, the effects of dietary GSH on plasma and liver lipid levels were investigated with growing rats fed on a high cholesterol diet.

\section{MATERIALS AND METHODS}

Animals and diets. Male albino rats of the Wistar strain weighing about $90 \mathrm{~g}$ were used. The animals were individually housed in suspended wire cages in a temperature-controlled $\left(24^{\circ} \mathrm{C}\right)$ room operated on a $12 \mathrm{hr}$ 
cycle of light (06:00 to 18:00) and dark. The animals were fed on the experimental diets ad libitum for 3 weeks. The composition of the basal diet containing cholesterol was as follows $(\%)$ : casein, 25; sucrose, 15; lard, 15; corn oil, 2; salt mixture, ${ }^{26)} 5$; vitamin mixtue, ${ }^{26)} 1$; choline chloride, 0.2 ; cholesterol, 1 ; sodium cholate, 0.25 ; and $\alpha$-starch to 100. In one experiment, the casein level was lowered to $10 \%$. The basal diet also contained $2700 \mathrm{IU}$ vitamin $\mathrm{A}$, $230 \mathrm{IU}$ vitamin $\mathrm{D}$, and $12 \mathrm{mg}$ vitamin $\mathrm{E}$ per $100 \mathrm{~g}$. The changes of casein level and dietary supplementation were made at the expense of starch. Glutathione was obtained from Kyowa Hakko Co., Ltd., Tokyo. At the end of the feeding period, food was removed at 24:00 and animals were killed to obtain blood plasma and several organs between 11:00 and 12:00 on the next day.

Analytical methods. The total lipids of the liver were extracted by the method of Folch et al. ${ }^{27)}$ and used for the measurement of lipids. The total cholesterol in the liver and plasma was measured by the method of $\mathrm{Zak} .{ }^{28)} \mathrm{High}$ density lipoprotein (HDL) was separated by the heparinMn precipitation method ${ }^{29)}$ followed by the measurement of HDL-cholesterol. The plasma concentrations of HDL- cholesterol, triglyceride, and phospholipid were measured enzymatically with commercial kits (Wako Pure Chemical Ind., Osaka). The contents of triglyceride and phospholipid in the liver were measured by the methods of Fletcher $^{30)}$ and Bartlett, ${ }^{31)}$ respectively. The statisticad analysis of experimental data was done by one-way analysis of variance; comparisons were made using the least significant difference (LSD) test to find which pairs of means were significantly different at $p<0.05 .{ }^{32)}$

\section{RESULTS}

Table I shows the growth, food consumption, and weight of several organs in rats fed on diets containing graded levels of GSH. The dietary addition of GSH did not affect body weight gain up to the $2.5 \%$ level, but the addition of $5 \%$ GSH resulted in a marked depression and in a slight diarrhea throughout the feeding period. Food intake was decreased as the addition level of GSH was increased.

Table I. Body Weight Gain, Food Intake, and Organ Weight in Rats Fed on Diets Containing Graded Levels of Glutathione

\begin{tabular}{|c|c|c|c|c|c|}
\hline \multirow{2}{*}{ Diet } & \multirow{2}{*}{$\begin{array}{l}\text { Body wt gain } \\
\text { (g/21 days) }\end{array}$} & \multirow{2}{*}{$\begin{array}{l}\text { Food intake } \\
\text { (g/21 days) }\end{array}$} & \multicolumn{3}{|c|}{ Organ weight $(\%$ body wt) } \\
\hline & & & Liver & Kidney & Spleen \\
\hline $25 \%$ Casein $(25 \mathrm{C})$ & $116 \pm 4^{\mathrm{ab}, 1}$ & $265 \pm 6^{a}$ & $5.65 \pm 0.05^{\mathrm{a}}$ & $0.853 \pm 0.009^{\mathrm{a}}$ & $0.264 \pm 0.004^{\mathrm{a}}$ \\
\hline $25 \mathrm{C}+0.75 \% \mathrm{GSH}$ & $119 \pm 4^{\mathrm{a}}$ & $258 \pm 4^{a b}$ & $5.73 \pm 0.09^{\mathrm{a}}$ & $0.867 \pm 0.019^{\mathrm{ab}}$ & $0.261 \pm 0.004^{\mathrm{a}}$ \\
\hline $25 \mathrm{C}+1.50 \% \mathrm{GSH}$ & $115 \pm 6^{\mathrm{ab}}$ & $245 \pm 6^{\mathrm{b}}$ & $5.61 \pm 0.14^{\mathrm{a}}$ & $0.897 \pm 0.016^{\mathrm{bc}}$ & $0.270 \pm 0.006^{\mathrm{a}}$ \\
\hline $25 \mathrm{C}+2.50 \% \mathrm{GSH}$ & $106 \pm 3^{b}$ & $231 \pm 3^{c}$ & $5.76 \pm 0.14^{\mathrm{a}}$ & $0.923 \pm 0.006^{\mathrm{c}}$ & $0.270 \pm 0.005^{\mathrm{a}}$ \\
\hline $25 \mathrm{C}+5.00 \% \mathrm{GSH}$ & $52 \pm 4^{\mathrm{c}}$ & $163 \pm 3^{d}$ & $5.73 \pm 0.17^{\mathrm{a}}$ & $1.035 \pm 0.015^{\mathrm{d}}$ & $0.306 \pm 0.008^{b}$ \\
\hline
\end{tabular}

1 Values are means \pm S.E. for 6 rats; values in a column not sharing the same superscript letter are significantly different at $p<0.05$.

Table II. Plasma Lipid Concentration in Rats Fed on Diets Containing Graded Levels of Glutathione

\begin{tabular}{|c|c|c|c|c|}
\hline \multirow{2}{*}{ Diet } & \multicolumn{4}{|c|}{ Plasma lipid concentration $(\mathrm{mg} / 100 \mathrm{ml})$} \\
\hline & Total $\mathrm{CHOL}^{2}$ & HDL-CHOL & $\mathrm{TG}^{3}$ & $\mathrm{PL}^{4}$ \\
\hline $25 \%$ Casein $(25 \mathrm{C})$ & $244 \pm 15^{a, 1}$ & $23.5 \pm 0.9^{\mathrm{a}}$ & $166 \pm 12^{\mathrm{a}}$ & $176 \pm 6^{a}$ \\
\hline $25 \mathrm{C}+0.75 \% \mathrm{GSH}$ & $178 \pm 9^{b}$ & $29.5 \pm 1.2^{\mathrm{b}}$ & $146 \pm 6^{\mathrm{ab}}$ & $161 \pm 7^{\mathrm{ab}}$ \\
\hline $25 \mathrm{C}+1.50 \% \mathrm{GSH}$ & $164 \pm 7^{b}$ & $32.8 \pm 1.0^{\mathrm{b}}$ & $125 \pm 16^{\mathrm{bc}}$ & $148 \pm 5^{b}$ \\
\hline $25 \mathrm{C}+2.50 \% \mathrm{GSH}$ & $149 \pm 6^{b}$ & $37.3 \pm 1.6^{\mathrm{c}}$ & $113 \pm 7^{\mathrm{cd}}$ & $151 \pm 3^{b}$ \\
\hline $25 \mathrm{C}+5.00 \% \mathrm{GSH}$ & $176 \pm 11^{b}$ & $42.3 \pm 2.0^{\mathrm{d}}$ & $88 \pm 8^{d}$ & $151 \pm 8^{b}$ \\
\hline
\end{tabular}

1 Values are means \pm S.E. for 6 rats; values in a column not sharing the same superscript letter are significantly different at $p<0.05$.

2 Cholesterol.

3 Triglyceride.

4 Phospholipid. 
The weights of kidney and spleen were slightly enlarged in rats fed on diets containing high levels of GSH while liver weight was not altered.

As shown in Table II, dietary addition of GSH lowered the plasma total cholesterol level and inversely increased the HDL-cholesterol level as compared with GSH-unsupplemented control diet. Plasma triglyceride and phospholipid levels were decreased by the dietary GSH. As shown in Table III, the contents of cholesterol and triglyceride in the liver decreased as the addition level of GSH was increased, but the liver phospholipid content was slightly higher in rats fed on diets containing higher levels of GSH.

Tables IV and $\mathrm{V}$ show the comparative effects of $2.5 \% \mathrm{GSH}$ and its constituting amino acids on plasma and liver lipid levels. The contents of cholesterol and triglyceride in the liver were lower in rats fed on the diet containing $2.8 \%$ amino acid mixture or $0.99 \%$ cysteine as well as $2.5 \%$ GSH. Similarly, plasma lipid

TABle III. LiVer Lipid CONTENT In Rats Fed on Diets Containing Graded LEVELS OF GLUTATHIONE

\begin{tabular}{cccc}
\hline & \multicolumn{3}{c}{ Liver lipid content (mg/g wet) } \\
\cline { 2 - 4 } Diet & CHOL & TG & PL \\
\hline $25 \%$ Casein (25C) & $86.9 \pm 1.9^{\mathrm{a}, 1}$ & $95.1 \pm 1.7^{\mathrm{a}}$ & $19.1 \pm 0.6^{\mathrm{a}}$ \\
$25 \mathrm{C}+0.75 \%$ GSH & $82.0 \pm 1.7^{\mathrm{a}}$ & $92.0 \pm 1.8^{\mathrm{ab}}$ & $19.9 \pm 1.1^{\mathrm{ab}}$ \\
$25 \mathrm{C}+1.50 \%$ GSH & $75.4 \pm 1.1^{\mathrm{b}}$ & $84.4 \pm 2.9^{\mathrm{b}}$ & $19.5 \pm 0.9^{\mathrm{a}}$ \\
$25 \mathrm{C}+2.50 \%$ GSH $63.2 \pm 1.5^{\mathrm{c}}$ & $70.7 \pm 2.3^{\mathrm{c}}$ & $22.0 \pm 0.6^{\mathrm{bc}}$ \\
$25 \mathrm{C}+5.00 \%$ GSH $52.0 \pm 1.8^{\mathrm{d}}$ & $56.2 \pm 3.8^{\mathrm{d}}$ & $22.8 \pm 0.5^{\mathrm{c}}$ \\
\hline 1 & Values are means \pm S.E. for 6 rats; values in a \\
column not sharing the same superscript letter are \\
significantly different at $p<0.05$.
\end{tabular}

Table IV. Comparison of the Effects of Glutathione and Its Constituting Amino Acids on Body Weight Gain, Food Intake and Liver Lipid Content in Rats

\begin{tabular}{|c|c|c|c|c|c|}
\hline \multirow{2}{*}{ Diet } & \multirow{2}{*}{$\begin{array}{l}\text { Body wt gain } \\
\text { (g/21 days) }\end{array}$} & \multirow{2}{*}{$\begin{array}{l}\text { Food intake } \\
\text { (g/21 days) }\end{array}$} & \multicolumn{3}{|c|}{ Liver lipid content (mg/g wet) } \\
\hline & & & CHOL & TG & PL \\
\hline $25 \%$ Casein $(25 \mathrm{C})$ & $116 \pm 4^{\mathrm{ab}, 1}$ & $265 \pm 6^{a}$ & $86.9 \pm 1.9^{\mathrm{a}}$ & $95.1 \pm 1.7^{\mathrm{a}}$ & $19.1 \pm 0.6^{\mathrm{ab}}$ \\
\hline $25 \mathrm{C}+2.50 \% \mathrm{GSH}$ & $106 \pm 3^{a}$ & $231 \pm 3^{b}$ & $63.2 \pm 1.5^{\mathrm{b}}$ & $70.7 \pm 2.3^{b}$ & $22.0 \pm 0.6^{\mathrm{cd}}$ \\
\hline $25 \mathrm{C}+2.80 \% \mathrm{AAmix}^{2}$ & $118 \pm 4^{\mathrm{ab}}$ & $256 \pm 6^{\mathrm{ac}}$ & $59.0 \pm 1.6^{\mathrm{b}}$ & $70.8 \pm 2.2^{b}$ & $22.6 \pm 0.5^{\mathrm{c}}$ \\
\hline $25 \mathrm{C}+1.20 \% \mathrm{Glu}^{3}$ & $118 \pm 5^{\mathrm{ab}}$ & $266 \pm 8^{a}$ & $81.8 \pm 1.7^{\mathrm{a}}$ & $94.5 \pm 2.6^{\mathrm{a}}$ & $17.8 \pm 1.2^{\mathrm{a}}$ \\
\hline $25 \mathrm{C}+0.99 \% \mathrm{CySH}^{3}$ & $106 \pm 4^{a}$ & $239 \pm 6^{\mathrm{bc}}$ & $62.3 \pm 1.1^{\mathrm{b}}$ & $70.8 \pm 2.0^{b}$ & $22.4 \pm 0.5^{\mathrm{cd}}$ \\
\hline $25 \mathrm{C}+0.61 \% \mathrm{Gly}^{3}$ & $122 \pm 5^{b}$ & $273 \pm 8^{a}$ & $84.7 \pm 0.8^{\mathrm{a}}$ & $91.7 \pm 1.9^{\mathrm{a}}$ & $20.6 \pm 0.4^{\mathrm{bd}}$ \\
\hline
\end{tabular}

1 Values are means \pm S.E. for 6 rats; values in a column not sharing the same superscript letter are significantly different at $p<0.05$.

2 Composed of $1.20 \%$ Glu, $0.99 \%$ CySH and $0.61 \%$ Gly, and corresponds to $2.50 \% \mathrm{GSH}$.

3 Corresponds to the amount of amino acid included in $2.50 \% \mathrm{GSH}$.

Table V. Comparison of the Effects of Glutathione and Its Constituting Amino acids on Plasma lipid Concentration in Rats

\begin{tabular}{clccc}
\hline \multirow{2}{*}{ Diet } & \multicolumn{3}{c}{ Plasma lipid concentration $(\mathrm{mg} / 100 \mathrm{ml})$} \\
\cline { 2 - 4 } & Total CHOL & HDL-CHOL & TG & PL \\
\hline $25 \%$ Casein $(25 \mathrm{C})$ & $244 \pm 15^{\mathrm{a}, 1}$ & $23.5 \pm 0.9^{\mathrm{a}}$ & $166 \pm 12^{\mathrm{ab}}$ & $176 \pm 6^{\mathrm{a}}$ \\
$25 \mathrm{C}+2.50 \%$ GSH & $149 \pm 6^{\mathrm{b}}$ & $37.3 \pm 1.6^{\mathrm{b}}$ & $113 \pm 7^{\mathrm{c}}$ & $151 \pm 3^{\mathrm{bc}}$ \\
$25 \mathrm{C}+2.80 \%$ AAmix & $157 \pm 5^{\mathrm{b}}$ & $32.2 \pm 1.3^{\mathrm{c}}$ & $150 \pm 17^{\mathrm{ac}}$ & $155 \pm 6^{\mathrm{bc}}$ \\
$25 \mathrm{C}+1.20 \%$ Glu & $220 \pm 8^{\mathrm{ac}}$ & $24.0 \pm 2.4^{\mathrm{a}}$ & $171 \pm 20^{\mathrm{a}}$ & $164 \pm 7^{\mathrm{ab}}$ \\
$25 \mathrm{C}+0.99 \%$ CySH & $143 \pm 8^{\mathrm{b}}$ & $31.9 \pm 1.2^{\mathrm{c}}$ & $132 \pm 10^{\mathrm{bc}}$ & $146 \pm 10^{\mathrm{b} .}$ \\
$25 \mathrm{C}+0.61 \%$ Gly & $209 \pm 12^{\mathrm{c}}$ & $27.2 \pm 0.6^{\mathrm{a}}$ & $139 \pm 7^{\mathrm{ac}}$ & $168 \pm 7^{\mathrm{ac}}$ \\
\hline
\end{tabular}

1 Values are means \pm S.E. for 6 rats; values in a column not sharing the same superscript letter are significantly different at $p<0.05$. 
Table Vi. Comparison of the Effects of Glutathione, Cysteine, and Glycine on Body Weight Gain, Food Intake, and Plasma Lipid Concentration in Rats Fed on a Low Protein Diet

\begin{tabular}{|c|c|c|c|c|c|c|}
\hline \multirow{2}{*}{ Diet } & \multirow{2}{*}{$\begin{array}{l}\text { Body wt gain } \\
\text { (g/21 days) }\end{array}$} & \multirow{2}{*}{$\begin{array}{l}\text { Food intake } \\
\text { (g/21 days) }\end{array}$} & \multicolumn{4}{|c|}{ Plasma lipid concentration $(\mathrm{mg} / 100 \mathrm{ml})$} \\
\hline & & & Total CHOL & HDL-CHOL & TG & PL \\
\hline $10 \%$ Casein $(10 \mathrm{C})$ & $65 \pm 4^{\mathrm{a} .1}$ & $281 \pm 9^{a}$ & $259 \pm 17^{\mathrm{a}}$ & $12.1 \pm 0.9^{\mathrm{a}}$ & $91 \pm 6^{\mathrm{a}}$ & $132 \pm 5^{\mathrm{a}}$ \\
\hline $10 \mathrm{C}+1.50 \% \mathrm{GSH}$ & $101 \pm 3^{b}$ & $297 \pm 5^{a}$ & $114 \pm 5^{\mathrm{b}}$ & $31.9 \pm 1.3^{\mathrm{b}}$ & $85 \pm 6^{\mathrm{a}}$ & $116 \pm 4^{\mathrm{b}}$ \\
\hline $10 \mathrm{C}+0.59 \% \mathrm{CySH}^{2}$ & $92 \pm 5^{b}$ & $279 \pm 9^{a}$ & $122 \pm 7^{b}$ & $30.5 \pm 1.5^{\mathrm{b}}$ & $92 \pm 5^{\mathrm{a}}$ & $116 \pm 3^{b}$ \\
\hline $10 \mathrm{C}+3.00 \%$ Gly & $72 \pm 4^{\mathrm{a}}$ & $289 \pm 10^{\mathrm{a}}$ & $175 \pm 3^{c}$ & $23.1 \pm 1.4^{\mathrm{c}}$ & $90 \pm 6^{\mathrm{a}}$ & $120 \pm 4^{\mathrm{ab}}$ \\
\hline $\begin{array}{l}\text { Values are me } \\
\text { different at } p\end{array}$ & $\frac{ \pm}{05}$ S.E. for $6 r$ & s; values in & olumn not sh & ing the same & script 1 & significantly \\
\hline 2 Corresponds $t$ & he amount of & ySH included & in $1.5 \%$ GSH. & & & \\
\hline
\end{tabular}

concentrations except for triglyceride were significantly affected by the dietary GSH, amino acid mixture, and cysteine to the same extent. The addition of the other constituents of GSH, i.e., glutamic acid and glycine, had only slight effects on plasma and liver lipid levels.

Table VI shows the comparative effects of dietary GSH, cysteine, and glycine on growth, food consumption, and plasma lipid levels in rats fed on a $10 \%$ casein diet. The growth of animals was significantly promoted by the dietary addition of $1.5 \% \mathrm{GSH}$ as well as $0.59 \%$ cysteine which is equivalent to the $1.5 \% \mathrm{GSH}$ in sulfur level. The addition of GSH and cysteine to the low protein diet greatly decreased the plasma total cholesterol and significantly increased HDL-cholesterol to the same extent. Glutathione and cysteine slightly, but significantly, lowered the plasma phospholipid level while they did not affect the plasma triglyceride level. The dietary addition of a higher amount of glycine, which is known to affect plasma cholesterol level, ${ }^{12,33)}$ also reduced plasma total cholesterol and increased HDL-cholesterol, but the effect of glycine was smaller than those of GSH and cysteine.

\section{DISCUSSION}

The results obtained here indicate that GSH has a plasma cholesterol-lowering effect in both rats fed on $25 \%$ casein and $10 \%$ caein diets containing cholesterol. The effects of GSH could not be essentially distinguished from those of cysteine, suggesting that the effects of GSH are largely attributable to the cysteine residue of the tripeptide rather than the tripeptide itself or the other amino acid residues. The results are in accord with the earlier finding by Mann; ${ }^{18)}$ he investigated the effects of GSH on serum cholesterol level in monkeys fed on a cysteine-defficient diet containing cholesterol and found a serum cholesterol-lowering effect of the tripeptide although he employed only one low dosage level, $2.1 \mathrm{mmol}$ per day. It has been reported that glutamic acid $^{34)}$ and glycine, ${ }^{12,33)}$ the constituents of GSH, have a serum or plasma cholesterol-lowering effect when they were added to the diet at higher levels, but the dietary addition of these amino acids at lower levels did not have much effect as shown in Table V. This is consistent with our previous finding that only sulfur amino acids such as methionine and cystine of all the amino acids tested have significant effects on plasma cholesterol level when added to the diet at a low level $(1 \%)$, although various amino acids affect plasma cholesterol level when added to the diet at a higher level $(5 \%)$ in rats fed on a $25 \%$ casein diet containing cholesterol. ${ }^{8)}$

It has been reported that dietary added GSH has a methionine-sparing action and, therefore, it can be a cysteine source in chicks ${ }^{35}$ ) and rats. ${ }^{36)}$ Harter and Baker ${ }^{35)}$ showed that the methionine-sparing value of GSH was identical to that of cystine when $0.256 \%$ GSH was added to the sulfur amino acid-deficient basal 
diet containing $0.3 \%$ methionine. Our results also demonstrated that the cholesterollowering effect of GSH at $2.5 \%$ or $1.5 \%$ level was almost comparable to that of cysteine (Tables V and VI), suggesting the equivalency of GSH and cysteine even at higher addition levels. However, the nutritional efficacy of GSH as a cysteine source may be restricted to the addition level of at least up to $2.5 \%$, since dietary addition of GSH at a $5 \%$ level caused marked depressions in growth and food intake with a slight diarrhea.

It is considered that ingested GSH as well as other di- and tripeptides is taken up by intestinal epithelial cells by two different mechanisms; membrane hydrolysis followed by absorption of hydrolytic products, or absorption followed by intracellular hydrolysis. ${ }^{37)}$ Linder et al. ${ }^{38)}$ have demonstrated that reduced GSH can be transported intact into brush border membrane vesicles against a concentration gradient. On the other hand, $\gamma$ glutamyltransferase (EC 2.3.2.2) which catalyzes the transfer of $\gamma$-glutamyl groups from GSH as well as from other $\gamma$-glutamyl-containing compounds has been found in highest activity in the epithelial cell membrane of various organs including small intestine. ${ }^{39)}$ It is, however, not known which mechanism is predominant in the overall absorption of GSH. In any case, the diarrhea caused by dietary addition of $5 \% \mathrm{GSH}$ indicates that the capacity of the small intestine to hydrolyze and/or to absorb GSH is restricted.

The mechanism of the plasma cholesterollowering effects of sulfur amino acids such as cysteine and taurine has not been fully elucidated, but Yamanaka et al. ${ }^{40,41)}$ have recently reported the stimulation of fecal excretion of bile acids, especially chenodeoxycholic acid and its related bile acids, by the dietary addition of high level of taurine in mice fed on a high cholesterol diet. On the other hand, several reports have shown that the cholesterollowering effect of taurine is much smaller than that of cystine in rats fed on low protein diet containing cholesterol. ${ }^{12,16)}$ Thus, it is not known whether the effects of sulfur amino acids which can be metabolized to form taurine are entirely attributable to the effects of taurine. The mechanism of the cholesterollowering effects of sulfur compounds including GSH remains to be further elucidated.

\section{REFERENCES}

1) K. K. Carroll and R. M. G. Hamilton, J. Food Sci., 40, 18 (1975).

2) N. R. Yadav and I. E. Liener, Nutr. Rep. Int., 16, 385 (1977).

3) D. M. Kim, K. T. Lee, J. M. Reiner and W. A. Thomas, Exp. Mot. Pathol., 29, 385 (1978).

4) D. Kritchevsky, J. Am. Oil Chem. Soc., 56, 135 (1979).

5) Y. Nagata, K. Imaizumi and M. Sugano, Br. J. Nutr., 44, 113 (1980).

6) M. J. Gibney, Proc. Nutr. Soc., 41, 19 (1982).

7) A. H. M. Terpstra, G. Van Tintelen and C. E. West, J. Nutr., 112, 810 (1982).

8) K. Sugiyama, M. Mizuno and K. Muramatsu, $J$. Nutr. Sci. Vitaminol., 32, 623 (1986).

9) A. H. M. Terpstra, R. J. J. Hermus and C. E. West, "Animal and Vegetable Proteins in Lipid Metabolism and Atherosclerosis," ed. by M. J. Gibney and D. Kritchevsky, Alan R. Liss Inc., New York, 1983, pp. 19 49.

10) K. Yagasaki, K. Okada, K. Takagi and T. Irikura, Agric. Biol. Chem., 48, 1417 (1984).

11) K. Sugiyama, Y. Kushima and K. Muramatsu, Agric. Biol. Chem., 48, 2897 (1984).

12) K. Sugiyama, Y. Kushima and K. Muramatsu, Agric. Biol. Chem., 49, 3455 (1985).

13) K. Yagasaki, N. Ozawa and R. Funabiki, Nutr. Rep. Int., 33, 321 (1986).

14) K. Sugiyama, H. Akai and K. Muramatsu, J. Nutr. Sci. Vitaminol., 32, 537 (1986).

15) L. C. Fillios and G. V. Mann, Metabolism, 3, 16 (1954).

16) J. C. Seidel, N. Nath and A. E. Harper, J. Lipid Res., 1, 474 (1960).

17) E. G. Hill, J. Nutr., 89, 143 (1966).

18) G. V. Mann, Am. J. Clin. Nutr., 8, 491 (1960).

19) B. Feland, E. G. Fuqua and J. T. Smith, J. Nutr., 103, 1561 (1973).

20) R. G. Hermann, Cir. Res., 7, 224 (1959).

21) S. Abe and T. Kaneda, Nippon Eiyō Shokuryō Gakkaishi ( J. Jpn. Soc. Nutr. Food Sci., in Japanese), 28, 125 (1975).

22) K. Tsuji, T. Ichikawa, Y. Yamanaka, Y. Matsu-ura and M. Kawamura, Ganryu Amino-san (in Japanese), 6, 239 (1983)

23) H. E. Sauberlich, J. Nutr., 75, 61 (1961).

24) K. Muramatsu, H. Odagiri, S. Morishita and H. 
Takeuchi, J. Nutr., 101, 1117 (1971).

25) A. E. Harper, N. J. Benevenga and R. M. Wohlhueter, Physiol. Rev., 50, 428 (1970).

26) A. E. Harper, J. Nutr., 68, 405 (1959).

27) J. Folch, M. Lees and G. H. Sloane Stanley, J. Biol. Chem., 226, 497 (1957).

28) B. Zak, Am. J. Clin. Pathol., 27, 583 (1957).

29) M. Burnstein, H. R. Scholnick and R. Morfin, J. Lipid Res., 11, 583 (1970).

30) M. J. Fletcher, Clin. Chim. Acta, 22, 393 (1968).

31) G. K. Bartlett, J. Biol. Chem., 234, 466 (1959).

32) G. W. Snedecor and W. G. Cochran, "Statistical Methods," 6th Ed. (Japanese Ed.), Iowa State University Press, Ames, Iowa, 1967, Chapter 10.

33) M. B. Katan, L. H. M. Vroomen and R. J. J. Hermus, Atherosclerosis, 43, 381 (1982).
34) G. Bazzano, J. A. D'Elia and R. E. Olson, Science, 169, 1208 (1970).

35) J. M. Harter and D. H. Baker, Proc. Soc. Exp. Biol. Med., 156, 201 (1977).

36) N. Tateishi, M. Hirasawa, T. Higashi and Y. Sakamoto, J. Nutr., 112, 2217 (1982).

37) D. M. Matthews, Physiol. Rev., 55, 537 (1975).

38) M. Linder, G. De Burlet and P. Sudaka, Biochem. Biophys. Res. Commun., 123, 929 (1984).

39) L. L. Ross, L. Barber, S. S. Tate and A. Meister, Proc. Natl. Acad. Sci. U.S.A., 70, 2211 (1973).

40) Y. Yamanaka, K. Tsuji, T. Ichikawa, Y. Nakagawa and M. Kawamura, Ganryu Amino-san (in Japanese), 7, 257 (1984).

41) Y. Yamanaka, K. Tsuji and T. Ichikawa, J. Nutr. Sci. Vitaminol., 32, 287 (1986). 